\title{
Congenital Sucrase-Isomaltase Deficiency
}

National Cancer Institute

\section{Source}

National Cancer Institute. Congenital Sucrase-Isomaltase Deficiency. NCI Thesaurus.

Code C128190.

An autosomal recessive genetic disorder caused by mutations in the SI gene, encoding sucrase-isomaltase, intestinal. The condition is characterized by malabsorption and osmotic diarrhea. 